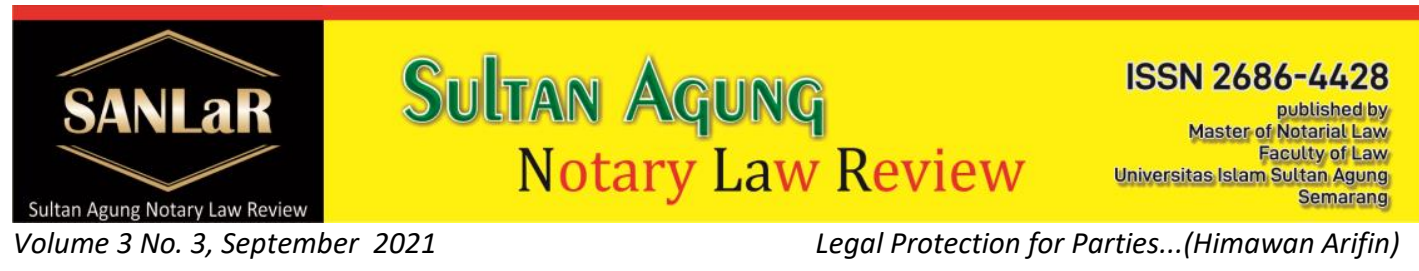

\title{
Legal Protection for Parties in Making Authentic Deeds from Legal Deviations by Notaries
}

\author{
Himawan Arifin*) \\ ${ }^{*}$ Faculty of Law, Universitas Islam Sultan Agung (UNISSULA) Semarang, E-mail: \\ himawanarifin9@gmail.com
}

\begin{abstract}
The position of a Notary is required by laws and regulations with a view to assisting and serving the public who need authentic written evidence, but a Notary in carrying out his profession commits a crime of forgery of letters in making an authentic deed so that a Notary who is consciously, intentionally or involved in making fake authentic deeds can be accounted for in criminal law. This writing aims to find out the legal protection for the victim who is harmed in making an authentic deed containing false information and the notary's responsibility in making the deed. The research method used in this thesis is a normative juridical approach, namely legal research carried out based on the main legal material by examining theories, concepts, legal principles and legislation related to research, this approach is also known as with a library approach, namely studying books, laws and regulations and other documents related to this research. The results of the study found that the Notary in making an authentic deed had fulfilled the elements of the criminal act of forging letters against an authentic deed in Article 263 paragraph 1 and Article 264 paragraph 1 to 1 of the Criminal Code. Legal protection for the victim takes legal action by reporting to the police and bringing the case to the Court of first instance, the level of appeal, and the level of cassation. So that the Notary is charged with responsibility in the form of imprisonment because it has been legally proven guilty of committing a criminal act of forging letters against an authentic deed.
\end{abstract}

Keywords: Legal; Protection; Parties; Authentic; Deeds; Deviations.

\section{Introduction}

A notary is a public official who is authorized to make an authentic deed as long as the making of a certain authentic deed is not reserved for other public officials. Making an authentic deed is required by laws and regulations in order to create certainty, order and legal protection. Notaries as public officials have a central role in enforcing the law in Indonesia because in addition to the large number of notaries, notaries are known to belong to the elite group in Indonesia. Notaries are authorized to make authentic deeds and have a strategic position in 
providing legal certainty to the community in particular and one's obligations. Mistakes on a notarial deed can cause a person's rights to be revoked or someone's burden to an obligation. ${ }^{1}$

Notary deed as an authentic deed that has an important function in social life to help and serve the community who need authentic written evidence, to create a certainty and legal protection. Authentic deeds are increasingly needed for written evidence, in line with the growing demands for legal certainty which is one of the principles of the rule of law. However, in practice, disputes often arise as a result of the product of the deed produced by the notary, criminal cases that bring the notary as a suspect as a consequence of the product of the deed he made are no longer new. Notaries cannot be separated from acts that deviate or violate the law, ${ }^{2}$

In practice, it is found that a violation of a legal product made by a notary is then qualified as a criminal act, if the notary commits an act of falsifying a letter or falsifying a deed, as referred to in articles 263 and 264 paragraph (1) of the Criminal Code so that it can cause harm to interested parties. ${ }^{3}$

In this study the authors take a case study of the Supreme Court's decision Number 146 K/PID/2015 concerning the making of an authentic deed by Notary Endang Murniati in the form of a deed of sale and purchase agreement, where the basis for making the deed is questionable because the making of the deed contains false information in the form of a signature one of the parties, where one of the parties feels that they have never signed the deed. Because one of the parties only knew about the making of the land swap agreement, not the PPJB deed.

From these problems a question arises for the author regarding how the legal protection for the parties who are harmed from legal deviations committed by a notary in making an authentic deed arises.

\footnotetext{
${ }^{1}$ Abdul Ghofur Anshori, 2009, Lembaga Kenotariatan Indonesia Perspektif Hukum dan Etika.Yogyakarta: UII Press, p. 25.

${ }^{2}$ Tetanoe Bernada, "Akibat Hukum Kelalaian Notaris Dalam Pembuatan Akta Perjanjian Sewa Menyewa', Jurnal Indonesian Notary, Vol.1, No.002, 2019, p. 3.

${ }^{3}$ Nur Cahyanti, "Sanksi Terhadap Notaris Yang Melakukan Tindak Pidana Menurut Peraturan Perundang-Undangan di Indonesia”, Jurnal Akta, Vol. 5, No. 1, 2018, p. 289.
} 


\section{Research Methods}

In the preparation of this study the author uses the approach method used is normative juridical, which means that this paper refers to written legal norms, both as outlined in the form of regulations and in other forms of literature. ${ }^{4}$ This research was conducted to get an overview of the application and how the legal protection for the parties who were harmed in making an authentic deed by a notary containing false information in the form of a fake signature of one of the parties was carried out.

The type of research conducted by the author is classified as analytical descriptive research. namely collecting all the necessary data and then connecting it with existing problems and analyzed based on legal theory associated with the problem under study, then the data is systematized and then analyzed to become the basis for drawing conclusions. Descriptive research is more focused on making use of existing concepts or creating new concepts logically and scientifically that has a clarifying function on the social phenomena in question. ${ }^{5}$

\section{Result and Discussion}

3.1. Legal protection for aggrieved parties in making an authentic deed by a notary containing false information in the Supreme Court's decision Number 146 K/PID/2015

The form of legal protection for the victim who was harmed in making an authentic deed by a notary based on the above case, the victim witness took the first step by reporting the actions of the defendant Notary Endang Murniati to the Yogyakarta Special Region Police to prove and test the truth of the signature contained in the binding agreement deed, buying and selling made by Notary Endang Murniati. Then from the results of the examination of the Criminal Laboratory Lab Number: 416/DTF/IV/2011 dated May 3, 2011 which was signed by Yayuk Murti Rahayu, Moh. Arif Budiarto, and Budi Santoso, The signature of the witness of the comparison victim is a different signature or is a fake signature. As a result of the defendant's actions, the victim witness suffered losses in the form of two parcels of land SHM Number 717 and 718.

\footnotetext{
${ }^{4}$ Soerjono Soekanto,1984, Pengantar Penelitian Hukum, Jakarta, Universitas Indonesia-Press, Jakarta, p. 53.

${ }^{5}$ Beni Ahmad Saebani, 2009, Metode Penilitian Hukum, Cetakan 1, Bandung: Pustaka Setia, p. 58.
} 
Because at the time of the signature date the victim was abroad (Oman), then the actions of the notary Endang Murniati were appointed to the Sleman District Court to account for their actions. In a legal deviation committed by Notary Endang Murniati, he is threatened with a criminal sentence in Article 263 paragraph (1) of the Criminal Code or Article 264 paragraph (1) of the Criminal Code that the act of falsifying a letter against an authentic deed is punishable by a maximum imprisonment of 8 (eight) years.

Based on the results of the research in the case above, Notary Endang Murniati has been legally proven to have committed a criminal act of forging letters and has violated the provisions of the UUJN in making an authentic deed.

Based on the results of the Supreme Court's decision to adjudicate, rejecting the cassation application II/Defendant Notary Endang Murniati and rejecting the cassation request from the petitioner for cassation I/the Public Prosecutor of the Sleman District Attorney, but only correcting the decision of the Yogyakarta High Court Number 84/PID/2014/PTY and the Court's decision State of Sleman Number 67/Pid.B/2012/PN.SImn. Which states that Notary Endang Murniati has been legally and convincingly proven guilty of committing a criminal act of falsifying letters in the form of an authentic deed, and imposing a sentence on Defendant Notary Endang Murniati with imprisonment for 1 (one) year and 9 (nine) months. Because the defendant has served a period of detention before the decision has permanent legal force so that it is completely deducted from the sentence imposed.

3.2. Notaries are categorized as committing legal deviations in making authentic deeds in the Supreme Court Decision Number 146 K/PID/2015

Deviant behavior can be interpreted as a tendency to deviate from a norm or not comply with certain norms, in other words, legal deviation is an act of crime.

A criminal act is an act that is prohibited by a rule of law, the prohibition is accompanied by threats or sanctions in the form of certain crimes for those who violate the prohibition. Regarding criminal provisions, it is not regulated in UUJN. UUJN only regulates sanctions for violations committed by Notaries against UUJN, these sanctions can be in the form of civil sanctions or administrative sanctions. While criminal liability for notaries is regulated in the Criminal Code if the notary commits a criminal act of forging letters. 
Based on the decision of the Supreme Court Number $146 \mathrm{~K} / \mathrm{PID} / 2015$, that a notary is categorized as an act of legal deviation or committing a criminal act because in making an authentic deed in the form of a Sale and Purchase Agreement Deed Number 65 dated 31 May 2004, Power of Attorney to Sell Number 51 and 52 dated 30 September 2004, made not in a condition according to real facts as written in the beginning of the deed with the sentence "Today, September 30, 2004 appear before me, a notary," in fact, the appellant Gregory Daryanto was not before the defendant notary Endang Murniati, no was in Yogyakarta, not in Indonesia but was in Oman (Middle East).Likewise, in the closing part of the deed, the sentence "Thus this deed was made and signed and closed on the day and date as mentioned above" in fact it is not as written by the Defendant Endang Murniati because the signature is not identical (false) with the signature of witness Gregory Daryanto by Therefore, the Defendant's act of making a letter whose contents are not proper (incorrect) or making a letter in such a way as to show the origin of the letter which is not true is an act of forgery of a letter so that the element of forgery of a letter has been fulfilled.

In making an authentic deed, basically it must contain the wishes and desires of the parties and contain the certainty of the day, date, month and year. So that it does not cause legal problems in the future, before the parties sign the notary, the notary should read the contents of the deed first in front of the parties in order to create a formal proof of power which states that the notary deed must provide certainty about what is stated and the certainty of all things included and described in the deed is the truth and in accordance with the wishes of the parties who appear before a notary.

\subsection{The notary's responsibility for the deed he made contains false information on the decision of the Supreme Court Number 146 K/PID/2015}

The position of a notary is present in society with the will of the rule of law in the form of a state as the implementation of the state in providing services to the community with the aim of helping the community in order to provide authentic written evidence regarding legal conditions, events and actions and an authentic evidence recognized by the state ${ }^{6}$.

A notary as a public official (openbaar ambtenaar) who is authorized to make an authentic deed may be responsible for carrying out his duties in making the

\footnotetext{
${ }^{6}$ Deen, Thaufiq., Ong Argo Victoria \& Sumain. (2018). Public Notary Services In Malaysia. JURNAL AKTA: Vol. 5, No. 4, 1017-1026. Retrieved from http://jurnal.unissula.ac.id/index.php/akta/article/view/4135 
deed. One of the responsibilities of a notary is criminal liability for the deed he made. Criminal liability for notaries is regulated in the Criminal Code if the notary commits a criminal act of forging letters.

Criminal liability is the responsibility of a person for a criminal act he has committed. In essence, criminal liability is a mechanism built by criminal law to react to an agreement to reject a certain act. ${ }^{7}$

As stated in the Supreme Court Decision Number $146 \mathrm{~K} / \mathrm{PID} / 2015$, the case is that the Defendant notary Endang Murniati, on Monday 31 May 2004, or at least at another time which is still included in 2004, is located at the Notary Office/PPAT Endang Murniati Jalan Colombo Number 2A, Catur Tunggal Village, Kec. Depok, Sleman Regency or at least in other places that are still included in the jurisdiction of the Sleman District Court, have made a forged letter or falsified a letter that can give rise to a right, an agreement or debt relief, or which is intended as evidence of something with the intent to use or order another person to use the letter as if it were true and not fake, are threatened if such use can cause losses due to forgery of the letter.

Based on the facts revealed in the trial and supported by valid evidence, the Panel of Judges at the first level, at the appeal level, and at the cassation level stated that Defendant Endang Murniati was legally and convincingly proven guilty of committing the crime of forging a letter in the form of an authentic deed. Notary Endang Murniati was charged with criminal responsibility because in carrying out his position he was proven guilty of committing a crime as regulated in Articles 263 and 264 of the Criminal Code.

Based on the formulation of Article 264 of the Criminal Code above, the actions that can be punished according to Article 264 of the Criminal Code are in addition to fulfilling all the elements in Article 263 of the Criminal Code plus a falsified letter in the form of authentic deeds. in the form determined by law by or before a public official authorized for that at the place where the deed was made. Thus, if all the elements of error have been met, the notary who commits the crime of forging letters can be held criminally responsible. And vice versa, if the elements are not met then it cannot be held criminally responsible.

${ }^{7}$ Chairul Huda, 2011, Dari 'Tiada Pidana Tanpa Kesalahan' menuju kepada 'Tiada Pertanggung Jawaban Pidana Tanpa Kesalahan', Jakarta: Kencana, p. 71. 


\section{Closing}

1). Legal protection for the aggrieved party in making an authentic deed by a notary containing false information according to the Supreme Court's decision Number 146 K/PID/2015 the victim takes legal action by reporting to the police regarding the fake signature contained in the agreement deed binding sale and purchase and power of attorney to sell made by the defendant notary Endang Puriati, then raised the case to the court of first instance, the level of appeal, and the level of cassation. The results of the decision stated that the defendant Endang Puriati had been legally and convincingly proven guilty of committing a criminal act of forging letters in the form of an authentic deed. 2). Notaries can be categorized as committing legal deviations in terms of making an authentic deed according to the decision of the Supreme Court Number 146 K/PID/2015, namely because it has fulfilled the elements of the criminal act of forging letters against an authentic deed in Article 263 paragraph 1 of the Criminal Code, Article 264 paragraph 1 to 1 of the Criminal Code. Because a notary is a public official who is authorized to make an authentic deed, the making of a deed must be based on the forms and procedures stipulated in the UUJN. 3). The notary's responsibility for the authentic deed he made contains false information according to the Supreme Court's Decision Number $146 \mathrm{~K} / \mathrm{PID} / 2015$ that the defendant notary Endang Puriati is charged with criminal responsibility because he has been legally proven guilty of committing the crime of forging letters against the authentic deed contained in Article 263 of the Criminal Code and Article 264 paragraph 1 to 1 of the Criminal Code. Because the act that can be punished according to Article 264 of the Criminal Code must contain all the elements contained in Article 263 of the Criminal Code, so that the panel of judges sentenced the defendant to imprisonment for 1 (one) year and 9 (nine) months.

\section{References}

Journals:

[1] Deen, Thaufiq., Ong Argo Victoria \& Sumain. (2018). Public Notary Services In Malaysia. JURNAL AKTA: Vol. 5, No. 4, 1017-1026. Retrieved from http://jurnal.unissula.ac.id/index.php/akta/article/view/4135

[2] Nur Cahyanti, "Sanksi Terhadap Notaris Yang Melakukan Tindak Pidana Menurut Peraturan Perundang-Undangan di Indonesia", Jurnal Akta, Vol. 5, No. 1, 2018, p. 289. 
[3] Tetanoe Bernada, "Akibat Hukum Kelalaian Notaris Dalam Pembuatan Akta Perjanjian Sewa Menyewa', Jurnal Indonesian Notary, Vol.1, No.002, 2019, p. 3.

Books:

[1] Abdul Ghofur Anshori, 2009, Lembaga Kenotariatan Indonesia Perspektif Hukum dan Etika.Yogyakarta: UII Press

[2] Soerjono Soekanto,1984, Pengantar Penelitian Hukum, Jakarta, Universitas Indonesia-Press, Jakarta

[3] Beni Ahmad Saebani, 2009, Metode Penilitian Hukum, Cetakan 1, Bandung: Pustaka Setia

[4] Chairul Huda, 2011, Dari 'Tiada Pidana Tanpa Kesalahan' menuju kepada 'Tiada Pertanggung Jawaban Pidana Tanpa Kesalahan', Jakarta: Kencana 